\title{
Internationalisation and Innovation Intensities of Polish Manufacturing Firms: A Close Nexus?
}

\author{
Tomasz Brodzicki
}

\begin{abstract}
A B S T R A C T
Objective: The paper aims at the empirical identification of the nexus between innovation and internationalisation intensities in a sample of Polish manufacturing companies.

Research Design \& Methods: Using a unique dataset combining micro-level financial data from InfoCredit and results from an extensive survey we follow the approach of Altomonte, Aquilante, Ottaviano \& Bekes (2013). We define innovation and internationalisation intensities and analyse the two dimensions disjointly and then simultaneously use formal econometric tools.
\end{abstract}

Findings: Both dimensions are closely and robustly correlated. There is some evidence for the causality going from innovation to internationalisation. Polish manufacturing companies have in general low innovation and internationalisation intensity. Rising innovation intensity allows companies to become more internationalised and in particular, it raises their probability of exporting. Mean characteristics of firms, such as employment, sales or productivity, change along the two examined dimensions.

Implications \& Recommendations: Our results firmly support the postulates of the heterogeneous firms' trade theory. The results strongly support the introduction of a new type of economic policy in which internationalisation promotion and innovation promotion are simultaneously targeted at the level of a firm.

Contribution \& Value Added: We extensively analyse innovation and internationalisation intensities for manufacturing firms from Poland. Using a logit model we show their impact on the likelihood of exporting. We furthermore apply the classification of exporting firms along temporal and geographical dimensions identifying main features and links to the key dimensions.

\begin{tabular}{ll}
\hline Article type: & research paper \\
Keywords: & $\begin{array}{l}\text { innovation intensity; Internationalisation intensity; firms heteroge- } \\
\text { neity; logit model; Poland }\end{array}$ \\
JEL codes: & F14, O31, C21, C26
\end{tabular}

Received: 4 November $2016 \quad$ Revised: 28 December $2016 \quad$ Accepted: 17 January 2017

\section{Suggested citation:}

Brodzicki T. (2017). Internationalisation and Innovation Intensities of Polish Manufacturing Firms. A Close Nexus? Entrepreneurial Business and Economics Review, 5(1), 91-109, DOI: http://dx.doi.org/10.15678/EBER.2017.050106 


\section{INTRODUCTION}

For many years economic theory assumed for the sake of simplicity that firms are symmetric or homogeneous. This assumption was also present in a key monopolistic competition model of Dixit and Stiglitz (1977) which laid the foundation for the new trade theory of Krugman and others (Krugman 1979, 1980). In a seminal paper, Nelson (1991) wrote that economic science had to recognise firms' differences explicitly to be closer to business management and strategy, in the case of which "firm differences are at the heart of their inquiry." It was only fully acknowledged with the rise of the new new trade theory (Melitz, 2003) under the pressure of surmounting micro-level evidence.

Firms differ in many dimensions, including their innovation potential and actual innovation performance. A critical review of theoretical economic and business management literature proves that innovation boosts firm's performance and competitiveness. The empirical results are, however, rather inconclusive. Most studies find individual returns to innovation to be significant and positive (Adams and Jaffe 1996). Some, on the contrary, find them to be insignificant or even negative. Numerous studies find evidence of a positive and robust correlation between firm's productivity, innovation, and internationalisation. Nonetheless, the direction of causality between them is still being discussed or questioned (Cieślik, Michałek \& Michałek, 2012).

The paper aims at the empirical identification of the nexus between the intensity of innovation and the intensity of internationalisation in a cross-sectional sample of Polish manufacturing companies. In the analysis, we utilise a unique firm-level financial dataset collected by InfoCredit and augmented with the results of an extensive qualitative survey. To some extent, we follow Altomonte et al. (2013) to obtain comparable and unbiased results.

The remainder of the paper is structured as follows. Section 2 reviews theoretical and empirical literature. Section 3 describes materials and methods and in particular, the survey and financial data utilised and provides definitions of innovation and internationalisation intensities. Section 4 presents results and discusses them. In particular, it analyses innovation and internationalisation intensities separately and then jointly and shows changing firm characteristics along the two dimensions. In the next step, it analyses the nexus between innovation and internationalisation with formal econometric methods, and finally, identifies the impact of innovation and internationalisation intensities on the likelihood of exporting by Polish manufacturing companies. The last section concludes.

\section{LITERATURE REVIEW}

The theory points to a positive relationship between innovation and internationalisation intensity. Technology-based models of international trade, such as a technology gap model of Posner (1961) or the product life-cycle model of Vernon (1966) postulate that at the firm-level that innovation is a key driver of exporting. The concepts were further developed by Krugman $(1979,1980)$, Dollar (1986), Jensen and Thurby (1987) or Segerstrom, Anant and Dinopoulos (1990). Melitz (2003), as it has been mentioned already, extended the analysis by incorporating productivity heterogeneity at the firm level giving rise to heterogeneous firms theory (HFT) that dominated the theoretical work in the last decade. 
The international business literature postulates that export behaviour depends on structural firm's characteristics, managerial and organisational factors, as well as incentives and disincentives to the internationalisation process (Leonidou, 1998). The resource-based view of a firm explains some of the principal causes of the observed firm heterogeneity (Barney, 1991; Hitt, Bierman, Shimizu, \& Kochhar, 2001). Last but not least, the innovation management literature postulates that innovative firms enter foreign markets to increase their total sales and thus decrease the average costs of innovation (Tidd \& Bessant, 2009). Furthermore, Wach (2015) discusses from the theoretical perspective the key role of innovation as an element of general entrepreneurial orientation and its impact on the internationalisation process of SMEs.

In the empirical literature, the linkages between internationalisation and innovation, previously analysed at the macro or meso level, are nowadays being investigated at firm-level with the growing body of evidence being accumulated (Bernard \& Jensen, 1999, 2004). Most studies find evidence of the so-called self-selection mechanism with a gain in productivity preceding entry into foreign markets (Bernard \& Jensen, 1999, Bernard, Jensen, \& Schott, 2006).

Innovation is one of the most important determinants of the likelihood of exporting, as well as of export intensity at the firm level. Evidence for the statement was provided, among others, Hirsch and Bijaoui (1985), Entorf, Krader, and Pohlmeier (1988), Kumar and Siddhrthan (1994), Wakelin (1998), Sterlacchini (1999), Basile (2001), Roper and Love (2002) or Caldera (2010). Most studies point to the actual causation going from innovation to exports (e.g. Cassiman \& Golovko, 2011; Becker \& Egger, 2013) and only a limited number of studies identifies the positive causation (e.g. Salomon \& Shaver 2005; Lileeva \& Trefler, 2010; Bratti \& Felice, 2012). In an interesting study, Aristei, Castellani and Franco (2013) indicate that prior imports increase the likelihood of exports through its positive impact both on firm's productivity and product innovations. There is also evidence for firms taking decision simultaneously on innovation and export market participation (e.g. Trefler, 2004; Aw, Roberts, \& Winston, 2007).

In a panel of European manufacturing companies (the EFIGE dataset), Altomonte, Aquilante, Bekes and Ottaviano (2013) indicate to a positive, broad, strong and robust relationship between the extent of internationalisation, productivity and innovation activities at firmlevel. Their extensive econometric analysis points to a causality going from innovation intensity to internationalisation intensity. The study will be treated as a benchmark for our analysis.

The marginal benefit of contemporaneous exporting and innovating increases with productivity (Aw, Roberts, \& Xu, 2011). Cassiman and Golovko (2011) show in a panel of Spanish firms that product innovation can lead to a decision to start exporting, an effect of which is further augmented by a reported indirect impact of innovation on productivity. The significant role of product innovations is also reported by Nassimbeni (2001) and Cassiman, Golovko and Martinez-Ros (2010).

Garcia-Quevedo, Pellegrinoa and Vivarellic (2014) demonstrate that innovation behaviour changes with firm's age. Younger firms' innovation conduct is to a large extent unpredictable, less persistent and driven mostly by demand-pull variables. Older companies' innovation activity is more persistent and driven primarily by technological and market determinants. Therefore, firm age has to be taken into account in the analysis alongside firm's size and productivity. 
Wakelin (1998) shows that the determinants of internationalisation behaviour vary between innovators and non-innovators in a panel of the UK firms and the capacity to innovate changes their conduct. Basile (2001), in turn, finds in a panel of Italian manufacturing companies that innovation capabilities to a large extent explain observed heterogeneity in export behaviour. The export intensity of innovating firms is identified as systematically higher than that of non-innovators.

Additionally, Castellani and Zanfei (2007) show that Italian firms more engaged in international activities exhibit contemporaneously superior economic and innovative performance. Active FDI markers are identified to have the highest productivity premia, the highest R\&D intensity, as well as better innovation performance. It is true that more productive firms self-select into international markets, but at the same time, their commitment to foreign markets is found to increase both firms' productivity and propensity to innovate.

Van Beveren and Vandenbussche (2010) show in a sample of Belgian firms that enterprises innovate in anticipation of entry into export markets. Monreal-Perez, AragonSanchez and Sanchez-Marin (2012) tackling the problem of endogeneity and controlling for firm productivity in a panel of Spanish manufacturing companies indicate that innovation induces firms to increase their export. They find, however, no support for learning-by-exporting onto product or process innovations.

Kafouros, Buckley, Sharp and Wang (2008) argue that not all firms can reap the rewards from innovation. The ability is reported to be restricted only to companies with a sufficient degree of internationalisation to reap benefits from innovation in many markets simultaneously. They furthermore provide evidence for internationalisation to enhance a business's capacity to improve performance through innovation.

In contrast to many mentioned studies, Damijan, Kostevc and Polanec (2010) exploring the causal links between innovation, productivity and export activities of Slovenian firms, find no evidence for product or process innovations increasing the probability of becoming a firsttime exporter. Past exporting, however, enhances the likelihood of a medium or large company becoming a process innovator with no similar impact on product innovation. The result could be at least partially attributed to specific features of that Balkan small-open economy.

Some evidence on the nexus has also been provided for Poland. Hegemajer and Kolasa (2011) study the effects of internationalisation on the economic performance of Polish companies, distinguishing between three modes of outward orientation: FDI, exporting and importing of capital goods. Internationalised firms are found to be superior regarding their size, productivity and productivity growth, capital intensity and wages. Cieślik et al. (2014) confirm the significance of firm characteristics for export performance for Central and Eastern European companies.

Cieślik, Michałek and Szczygielski (2016) analyse the relationship between various types of innovations and export performance in a panel of Polish firms in a relatively short period, 2008-2010. They control for human and physical capital endowment, firm size (employment size groups), the level of technological sophistication of a sector, as well as the presence of foreign capital, but are unable to control for the level of productivity. The likelihood of exporting is positively related to both product and process innovations, firm's size, human capital endowment measured by the share of university graduates in employment and foreign capital participation in the case of exporters. Also, the study by Brodzicki 
and Ciołek (2016) identifies the positive impact of innovation on the likelihood of Polish manufacturing companies to export after controlling for firm productivity.

\section{MATERIAL AND METHODS}

As the access to micro-level data for Polish enterprises is restricted, we conducted a survey within the research project described in acknowledgments on a sample of exporting and non-exporting enterprises, merging it with financial data provided by InfoCredit (information on databases is available at: http://www.infocredit.pl/en/aboutcompany/about-us.html) - a provider of data to the pan-European Amadeus database. The database includes detailed micro data on 125000 enterprises from Poland.

The following selection criteria were applied:

- an enterprise has a complete five year period of data availability,

- total sales per enterprise exceed 2m PLN (roughly 500k EUR) each year,

- exports exceed 1 million PLN each year (or approx. 250k EUR).

The use of the above criteria gave a database of approx. 7000 relatively large and mature enterprises, from which randomly selected ones were surveyed. 709 enterprises were effectively questioned with a direct contact by a pollster. From the above database, a subset of manufacturing enterprises was chosen for further analysis in the present paper. It means that we deal with 536 firms out of which 374 are exporters and 162 are non-exporters. $5.72 \%$ of manufacturing companies were micro-sized (employment of 9 or less) and $46.15 \%$ had employment of below 50 (micro or small sized in terms of employment). Only $3.55 \%$ had employment above 500 . The mean employment in our sample was 110 employees. At the same time, in order to obtain representative results, we calculated the shares of individual sectors in the population of all enterprises in Poland. These shares were used as weights in all calculations. Thanks to this, the results and findings can be interpreted not only as relevant for the selected group of enterprises, but also for the entire population of companies.

We have to note furthermore that our sample consists of rather large companies (the upper tail of distribution by firm size) which have at least 5-year continuity of financial reports (and thus have been active for at least five years).

We analyse internationalisation and innovation modes jointly and intensities rather than considering them separately. In their paper, Altomonte et al. (2013) define internationalisation intensity as a number of internationalisation modes in which a firm is active simultaneously, including the following: exporter, importer, outsourced or outsourcer status and FDI maker. The modes are non-exclusive, and thus internationalisation intensity ranges between 0 and 5 .

Taking into account the nature of the survey and available data in contrast to the benchmark study we adopt to following elements into account, broadening the concept of internationalisation intensities:

- exports,

- imports,

- the presence of foreign capital,

- being a part of a multinational enterprise (corporation), 
- close cooperation in sales on foreign markets,

- own sales abroad through own offices,

- exports constituting a significant share of company's sales,

- exporting on a permanent basis (not sporadically or ad hoc),

- FDI maker.

The modes considered are non-exclusive, and internationalisation extent ranges between 0 and 9 .

Innovation extent is defined in the present article as the number of different innovation modes in which a particular company is simultaneously involved. We take into account the following innovation inputs and output measures:

- the introduction of new products (radical innovations),

- the introduction of improvements in existing products (incremental innovations),

- the introduction of new or improved production process (process innovations),

- the introduction of new or enhanced organisation (organisational innovations),

- the functioning of R\&D unit (in-house R\&D),

- acquisition of R\&D from outside of the company (external R\&D),

- patents and patent applications,

- acquisition of licences,

- trademark applications.

Thus, our innovation extent, similarly to the internationalisation extent, ranges from 0 and 9 . Out of 536 manufacturing companies, only 23 or $4.29 \%$ have zero internationalisation intensity, and 32 or $5.97 \%$ have zero innovation intensity. They could be judged as totally passive in both dimensions.

In the empirical part of the article, we utilise formal descriptive statistical tools as well as econometric modelling - cross-sectional regression estimated with (conditional) OLS (as well as $\mathrm{MNL}, \mathrm{OL}$, and IV models, not shown here due to the article length restrictions) and in addition a logit model for the likelihood of exporting. The methodology follows the benchmark of Altomonte at al. (2013) and is fully described in Brodzicki (2016).

\section{RESULTS AND DISCUSSION}

We begin with the analysis of internationalisation intensity of manufacturing firms in our sample. Surprisingly, only $4.3 \%$ of manufacturing companies in our sample are purely domestic (please refer to Tables 1 and 3). 95.7\% are internationally active in at least one dimension or mode, and $79.3 \%$ has internationalisation intensity of two or more, and at the same time $11.0 \%$ of firms of five or more. The distribution of internationalisation intensity is clearly skewed to the right in accordance with our expectations, similarly to the distribution of productivity. To account for productivity differences as postulated by heterogeneous firm's theory, we calculated a number of productivity measures, including labour productivity (LP), capital productivity (CP), TFP or total productivity (TPROD). All kernel distribution estimates of productivity are skewed to the right. Very productive firms are rare, while companies with low productivity clearly dominate. In econometric modelling, both labour productivity and total 
productivity will be utilised. Due to data availability and the complexity of the measure, the use of TFP would significantly reduce the number of observations considered.

$69.8 \%$ of undertakings are exporters, while only $45.3 \%$ import (please refer to Table 1). $61.6 \%$ have a high export share in their total sales, while $43.8 \%$ export on a permanent basis (permanent exporters). $21.8 \%$ have foreign capital in their capital structure. $11.4 \%$ are part of a multinational enterprise. Only $9.5 \%$ are foreign direct investment makers, while only $4.5 \%$ cooperate in international sales with foreign subsidiaries or have established their sales offices abroad.

We now turn to the analysis of innovation intensity. Having adopted a very broad measure of innovation we see that $94 \%$ of manufacturing firms are active in innovation in at least one mode. However, the overall innovation intensity is low and clearly skewed to the right, similarly to the one observed for the internationalisation dimension. $46.1 \%$ of companies have innovation intensity of two or below, and only $12.7 \%$ have innovation intensity of five or more.

During the last three years, $28.9 \%$ of companies in our sample have introduced new products (please refer to Table 2). Incremental product innovations are more frequent in accordance with our expectations - they have been adopted in $2 / 3$ of firms. These are followed by the process (36.6\%) and organisational innovations (25.7\%). Around $1 / 4$ of companies in our sample obtained trademarks and $1 / 5$ patents or licenses. $15.1 \%$ of firms reports having an in-house R\&D lab while $14 \%$ commission specialised R\&D activity externally.

Table 1. Dimension of internationalisation (descriptive statistics)

\begin{tabular}{|c|c|c|}
\hline Internationalisation dimension & \# of firms & Frequency (\%) \\
\hline Exporters & 374 & 69.8 \\
\hline Importers & 243 & 45.3 \\
\hline Own sales offices & 24 & 4.5 \\
\hline Int. cooper. sales & 24 & 4.5 \\
\hline Foreign capital & 117 & 21.8 \\
\hline MNE & 61 & 11.4 \\
\hline FDI maker & 51 & 9.5 \\
\hline Permanent exporter & 235 & 43.8 \\
\hline Large export share & 330 & 61.6 \\
\hline Total & 536 & 100.0 \\
\hline
\end{tabular}

Notes: Modes of internationalisation are non-mutually exclusive.

Source: own elaboration from the survey and InfoCredit databases.

Mean firms' characteristics change with rising internationalisation intensity. Internationally active firms differ significantly from purely domestic companies (please refer to Table 3). Domestic companies are smaller in terms of mean sales or employment. They are foremost less productive (both in terms of labour productivity and total productivity). They also have lower overall innovation intensity. Purely domestic firms are on average younger than internationalised firms.

We have to note that none of the manufacturing companies in our sample attained a score of seven or above out of the possible maximum of nine. In general, internationalisation intensity increases with firms' size and age as measured by employment. Mean sales are the highest for companies with moderate levels of internationalisation coupled with average sales per employee. Average labour productivity 
and total productivity show a similar pattern. We thus have to control for this in the following econometric estimates. Average innovation intensity, on the other hand, increases steadily with rising internationalisation intensity, which is indicative of the nexus.

Table 2. Dimensions of innovation activities of firms (descriptive statistics)

\begin{tabular}{|c|c|c|}
\hline Innovation dimensions & \# of firms & Frequency (\%) \\
\hline New product & 155 & 28.9 \\
\hline Product (incremental) & 354 & 66.0 \\
\hline Process & 196 & 36.6 \\
\hline Organisational & 138 & 25.7 \\
\hline Own R\&D unit & 81 & 15.1 \\
\hline External R\&D & 75 & 14.0 \\
\hline Patents & 107 & 20.0 \\
\hline Licenses & 99 & 18.5 \\
\hline Trademarks & 131 & 24.4 \\
\hline Total & 536 & 100.0 \\
\hline
\end{tabular}

Notes: Modes of internationalisation are non-mutually exclusive.

Source: own elaboration from the survey and InfoCredit databases.

Table 4 illustrates, in turn, the changing firms' mean characteristic with increasing innovation intensity. In contrast, the patterns are less sharp or well-defined. Nonetheless, some can be identified. Innovation intensity increases with the increasing employment of firms and sales (with some disturbance in the relation). Innovation intensity increases with mean firm age and productivity as measured by the mean of both log total productivity and log labour productivity. Mean internationalisation intensity increases with rising innovation intensity with one major exception - firms with the highest innovation intensity.

We now turn to a simultaneous analysis of internationalisation and innovation intensities. Table 5 and Figure 1 give the frequencies in our sample of manufacturing companies. It is evident that the number of firms with zero intensities is low. On the other hand, the number of companies with low innovation and internationalisation intensities is the highest. Furthermore, moving along the diagonal (i.e. increasing internationalisation and innovation simultaneously) leads to a drop in the frequencies of firms. There are no companies present at the other extreme which is similar to the pattern observed in the benchmark study by Altomonte et al. (2013).

From the above, we know that one of the aspects we should control for is firm's size. Therefore, taking into account mean employment levels, we calculated the share of companies in total employment in our sample along the two intensities under scrutiny in the present paper. The result is given in Figure 2. It is evident, in comparison to Figure 1, that the shares shift towards firms with higher innovation and/or internationalisation intensities but not to a significant extent. It is clearly in contrast with the results obtained by Altomonte et al. (2013). Poland clearly lacks large firms with high innovation and internationalisation intensity - with size significant enough to induce an upward shift in higher overall international competitive potential. It can be mostly attributed to merely a recent shift in systemic paradigm - economic transition only started 27 years ago and more time is simply required for enterprises of that kind to emerge in the volatile market economy. 
Table 3. Internationalisation intensity and firm characteristics

\begin{tabular}{|c|c|c|c|c|c|c|c|c|c|c|}
\hline Intensity & No of firms & $\%$ & Cumulated \% & $\begin{array}{l}\text { Avg. Sales } \\
\text { (m PLN) }\end{array}$ & $\begin{array}{c}\text { Avg. Sales per } \\
\text { employee }\end{array}$ & $\begin{array}{l}\text { Avg. } \\
\text { Employ. }\end{array}$ & Mean Age & $\begin{array}{l}\text { Avg. In } \\
\text { (TPROD) }\end{array}$ & $\begin{array}{l}\text { Avg. } \\
\ln (L P)\end{array}$ & $\begin{array}{c}\text { Avg. } \\
\text { Innovation } \\
\text { intensity }\end{array}$ \\
\hline 0 & 23 & 4.3 & 4.3 & 8.1 & 210.6 & 38.5 & 18.2 & 2.535 & 4.924 & 2.174 \\
\hline 1 & 88 & 16.4 & 20.7 & 33.4 & 584.9 & 57.1 & 17.6 & 2.701 & 5.613 & 2.557 \\
\hline 2 & 122 & 22.8 & 43.5 & 39.5 & 513.8 & 76.9 & 21.0 & 3.000 & 5.591 & 2.697 \\
\hline 3 & 149 & 27.8 & 71.3 & 313.7 & 2139.2 & 146.6 & 23.5 & 2.846 & 5.717 & 2.752 \\
\hline 4 & 95 & 17.7 & 89.0 & 121.1 & 599.1 & 202.2 & 18.6 & 2.665 & 5.715 & 2.895 \\
\hline 5 & 52 & 9.7 & 98.7 & 97.8 & 564.3 & 173.3 & 20.5 & 2.691 & 5.592 & 3.173 \\
\hline 6 & 7 & 1.3 & 100.0 & 70.8 & 291.8 & 242.7 & 12.6 & 2.751 & 5.483 & 3.714 \\
\hline $7-9$ & $:$ & : & : & : & : & : & : & : & : & : \\
\hline Total & 536 & 100.0 & - & 122.0 & 967.7 & 126.0 & 20.4 & 2.795 & 5.625 & 2.761 \\
\hline
\end{tabular}

Notes: Modes of internationalisation are non-mutually exclusive.

Source: own elaboration from the survey and InfoCredit databases.

Table 4. Innovation Intensity and firm characteristics

\begin{tabular}{|c|c|c|c|c|c|c|c|c|c|c|}
\hline Intensity & No of firms & $\%$ & Cumulated \% & $\begin{array}{l}\text { Avg. Sales } \\
\text { (m PLN) }\end{array}$ & $\begin{array}{c}\text { Avg. Sales per } \\
\text { employee }\end{array}$ & $\begin{array}{l}\text { Avg. } \\
\text { Employ. }\end{array}$ & Mean Age & $\begin{array}{l}\text { Avg. In } \\
\text { (TPROD) }\end{array}$ & $\begin{array}{l}\text { Avg. } \\
\ln (L P)\end{array}$ & $\begin{array}{l}\text { Avg. Intern. } \\
\text { intensity }\end{array}$ \\
\hline 0 & 32 & 6.0 & 6.0 & 63.6 & 533.6 & 119.3 & 19.8 & 2.628 & 5.552 & 2.344 \\
\hline 1 & 86 & 16.0 & 22.0 & 32.0 & 449.4 & 71.3 & 19.4 & 2.725 & 5.542 & 2.523 \\
\hline 2 & 129 & 24.1 & 46.1 & 80.5 & 589.4 & 136.6 & 21.7 & 2.797 & 5.648 & 2.527 \\
\hline 3 & 115 & 21.5 & 67.6 & 335.2 & 2339.7 & 143.3 & 17.2 & 2.815 & 5.670 & 2.922 \\
\hline 4 & 106 & 19.8 & 87.4 & 85.9 & 644.8 & 133.2 & 20.6 & 2.841 & 5.693 & 2.811 \\
\hline 5 & 46 & 8.6 & 95.9 & 70.5 & 511.8 & 137.7 & 21.2 & 2.796 & 5.349 & 3.043 \\
\hline 6 & 17 & 3.2 & 99.1 & 62.9 & 660.5 & 95.2 & 29.8 & 3.035 & 5.981 & 3.412 \\
\hline 7 & 5 & 0.9 & 100.0 & 146.3 & 608.1 & 240.7 & 38.8 & 2.678 & 5.745 & 2.200 \\
\hline $8-9$ & $:$ & $:$ & & $:$ & $:$ & $:$ & $:$ & $:$ & $:$ & $:$ \\
\hline Total & 536 & 100.0 & - & 122.0 & 967.7 & 126.0 & 20.4 & 2.795 & 5.625 & 2.726 \\
\hline
\end{tabular}

Notes: of innovation activity are non-mutually exclusive.

Source: own elaboration from the survey and InfoCredit databases. 
Table 5. Internationalisation vs. innovation intensity (frequencies in the sample, \%)

\begin{tabular}{|c|c|c|c|c|c|c|c|c|c|c|c|c|}
\hline & \multicolumn{11}{|c|}{ Innovation intensity } \\
\hline & & 0 & 1 & 2 & 3 & 4 & 5 & 6 & 7 & 8 & 9 & Total \\
\hline \multirow{11}{*}{ 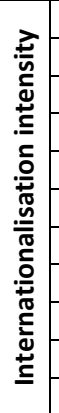 } & $\mathbf{0}$ & 0.37 & 0.75 & 2.43 & 1.31 & 1.12 & 0.00 & 0.00 & 0.00 & 0.00 & 0.00 & 5.97 \\
\hline & 1 & 1.31 & 2.80 & 3.54 & 4.85 & 1.87 & 1.49 & 0.19 & 0.00 & 0.00 & 0.00 & 16.04 \\
\hline & 2 & 1.31 & 4.85 & 5.97 & 5.78 & 4.10 & 2.05 & 0.00 & 0.00 & 0.00 & 0.00 & 24.07 \\
\hline & 3 & 0.37 & 3.54 & 3.36 & 7.28 & 4.29 & 2.24 & 0.37 & 0.00 & 0.00 & 0.00 & 21.46 \\
\hline & 4 & 0.75 & 3.73 & 3.36 & 5.60 & 3.73 & 2.24 & 0.37 & 0.00 & 0.00 & 0.00 & 19.78 \\
\hline & 5 & 0.00 & 0.56 & 2.80 & 2.05 & 2.24 & 0.75 & 0.19 & 0.00 & 0.00 & 0.00 & 8.58 \\
\hline & 6 & 0.00 & 0.19 & 0.75 & 0.93 & 0.37 & 0.75 & 0.19 & 0.00 & 0.00 & 0.00 & 3.17 \\
\hline & 7 & 0.19 & 0.00 & 0.56 & 0.00 & 0.00 & 0.19 & 0.00 & 0.00 & 0.00 & 0.00 & 0.93 \\
\hline & 8 & 0.00 & 0.00 & 0.00 & 0.00 & 0.00 & 0.00 & 0.00 & 0.00 & 0.00 & 0.00 & 0.00 \\
\hline & 9 & 0.00 & 0.00 & 0.00 & 0.00 & 0.00 & 0.00 & 0.00 & 0.00 & 0.00 & 0.00 & 0.00 \\
\hline & & 4.29 & 16.42 & 22.76 & 27.80 & 17.72 & 9.70 & 1.31 & 0.00 & 0.00 & 0.00 & 100.0 \\
\hline
\end{tabular}

Source: own elaboration from the survey and InfoCredit databases.

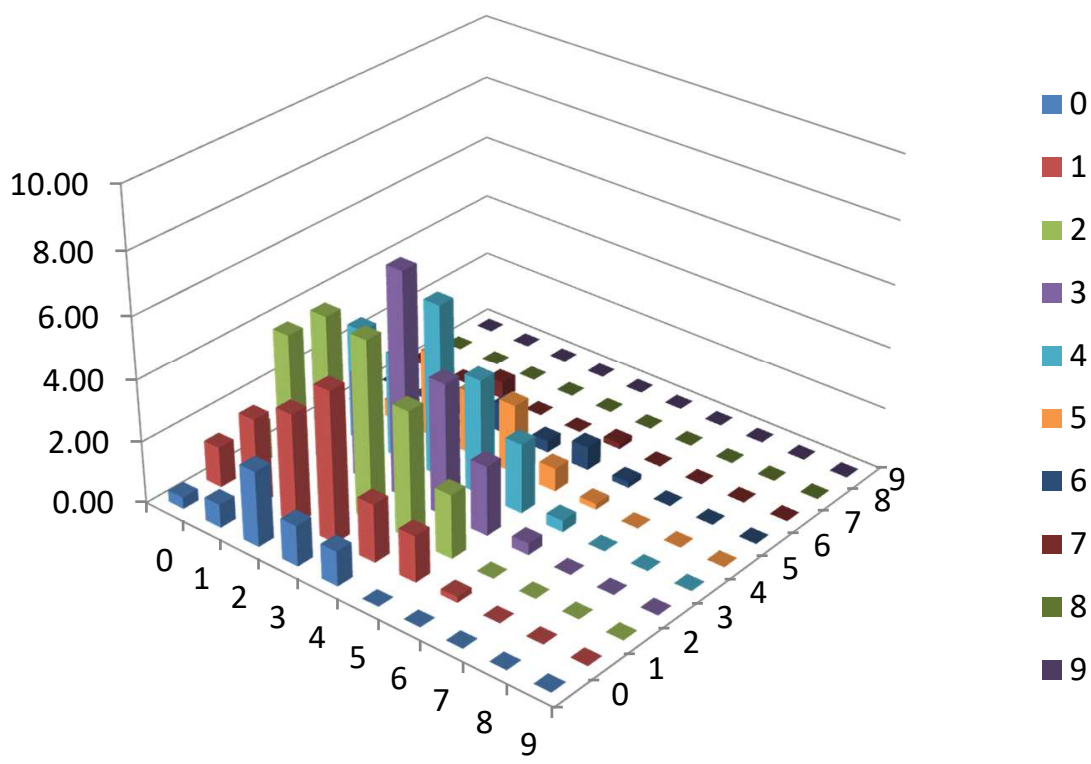

Figure 1. Internationalisation and innovation intensity (frequencies) Source: own elaboration from the survey and InfoCredit databases.

Following Onkelinx and Sleuwaegen (2010) analysis for Belgian SMEs, we want to investigate the exporting manufacturing firms in our sample from one more point of view. We classify the firms according to the observed differences in international scope (geographical dimension - narrow or wide) and the timing of internationalisation (early or late), thus obtaining four distinct groups of exporters and showing their frequencies and their basic characteristics observed in our sample. We then report on their overall innovation and internationalisation intensity - the principal aim of the present paper. Having analysed the distribution of the commencement of export activity along temporal di- 
mension (from the birth of the company) and the geographical scope of exports of the companies in our sample and noting that we are not dealing only with SMEs and the operation with the EU28 internal market, we have chosen the thresholds of five years since birth and ten export markets. We thus deal with born-globals (BG) companies which internationalised shortly after being set-up and at least to ten foreign markets. Born international firms (BI) start to export early but sales to fewer than ten foreign markets. Traditional internationalisers (TI) export to fewer than ten markets and start to export late (more than five years from the moment of setting up). Finally, born-again globals (BAG) export to 10 or more markets but started exporting late in their life-cycle. Similarly to Onkelinx and Sleuwaegen (2010), we did not find the results to be proportionally vulnerable to the choice of thresholds.

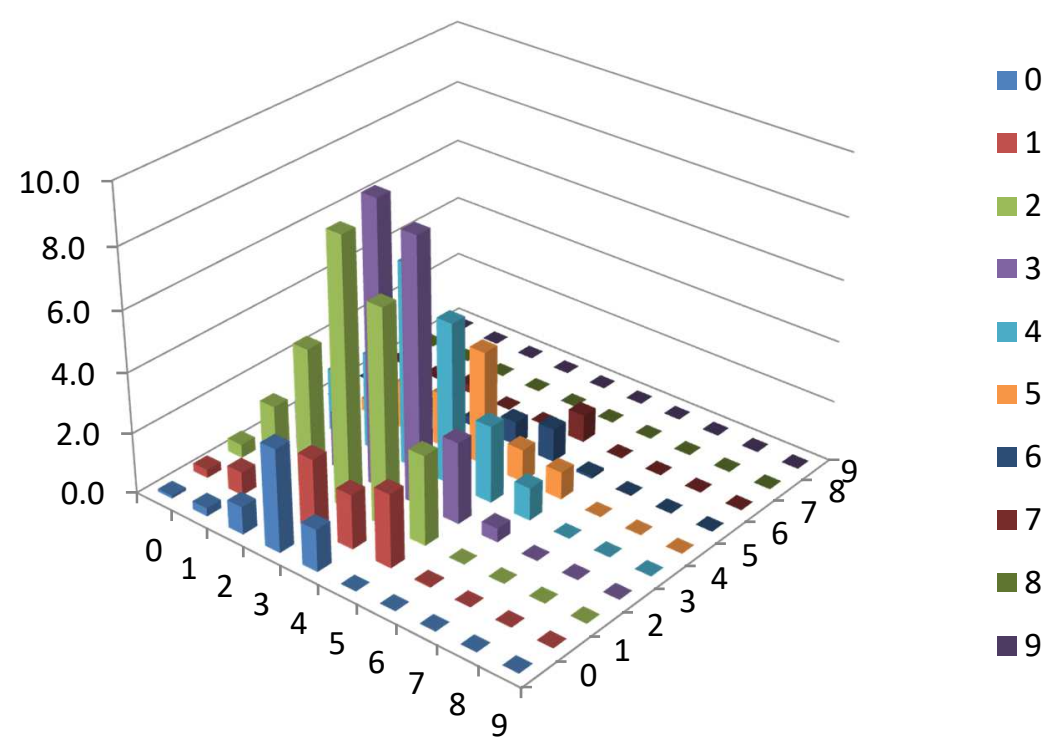

Figure 2. Internationalisation vs. innovation intensity (share in total employment) Source: own elaboration from the survey and InfoCredit databases.

In our sample of manufacturing companies, 370 are exporters and can be thus classified along the analysed dimensions. Most of the companies in our sample entered the foreign markets late (54.3\%) and $47.3 \%$ have a narrow scope (please refer to Table 6). Born internationals (31.4\%) and born-again globals (38.4\%) are the most frequent. Surprisingly, only $15.9 \%$ of firms are traditional internationalisers. Born global are rare (14.3\%).

Born internationals and traditional internationalisers are on average the smallest regarding mean sales and employment. Born-again globals are the largest in terms of employment, while born global in terms of average sales. Born internationals are the youngest, while traditional internationalisers the oldest. Productivity-wise, as measured by total productivity, is the lowest for born internationals and the highest on average for born globals with bornagain globals in the second place and traditional internationalisers not very far away. When 
we measure it by labour productivity, traditional internationalisers are in the first instance followed by born globals. Born internationals are once again least productive.

Table 6. Internationalisation and innovation intensity in four types of manufacturing exporters

\begin{tabular}{|c|c|c|c|c|c|c|c|c|}
\hline Type & Freq. \% & $\begin{array}{c}\text { Avg. Sales } \\
\text { (M PLN) }\end{array}$ & $\begin{array}{c}\text { Avg. } \\
\text { Employ. }\end{array}$ & $\begin{array}{c}\text { Mean } \\
\text { Age }\end{array}$ & $\begin{array}{c}\text { Avg. } \\
\text { In(TPROD) }\end{array}$ & $\begin{array}{c}\text { Avg. } \\
\text { In(LP) }\end{array}$ & $\begin{array}{c}\text { Avg. } \\
\text { INTER }\end{array}$ & $\begin{array}{c}\text { Avg. } \\
\text { INNOV }\end{array}$ \\
\hline TI & 15.9 & 82.3 & 121.2 & 29.89 & 2.896 & 5.914 & 2.796 & 3.356 \\
\hline BAG & 38.4 & 140.8 & 192.2 & 17.13 & 2.913 & 5.755 & 3.190 & 2.831 \\
\hline BI & 31.4 & 75.8 & 138.9 & 15.65 & 2.701 & 5.446 & 3.422 & 2.810 \\
\hline BG & 14.3 & 676.0 & 153.8 & 24.57 & 2.941 & 5.906 & 3.717 & 3.283 \\
\hline
\end{tabular}

Source: own elaboration from the survey and InfoCredit databases.

When we turn to mean intensity of internationalisation it is the lowest, in accordance with our expectations, for traditional internationalisers (2.796) and born-again globals (3.422). It is the highest for born globals (3.717). Innovation-wise, born-again globals and born internationals have the lowest innovation intensity, while it is significantly higher for traditional internationalisers (3.356) and born globals (3.283).

Following Altomonte et al. (2013), we start the econometric analysis by estimating a set of simple regression models for our broadest sample with exporters and non-exporters included. Models $\mathrm{O} 1, \mathrm{O} 2, \mathrm{O} 3$ and $\mathrm{O} 4$ in Table 7 are estimations of the following equations using OLS, respectively:

$$
\begin{gathered}
\text { INTER }_{i}=\alpha_{0}+\beta_{1} \text { INNOV }_{i}+\varepsilon_{i} \\
\text { INTER }_{i}=\alpha_{0}+\beta_{1} \text { INNOV }_{i}+\vartheta_{r}+\gamma_{e}+\varepsilon_{i} \\
\text { INTER }_{i}=\alpha_{0}+\beta_{1} \text { INNOV }_{i}+\beta_{2} \ln (T P R O D)_{i}+\vartheta_{r}+\gamma_{e}+\varepsilon_{i} \\
\text { INTER }_{i}=\alpha_{0}+\beta_{1} \text { INNOV }_{i}+\beta_{2} \ln (L P)_{i}+\vartheta_{r}+\gamma_{e}+\varepsilon_{i}
\end{gathered}
$$

where:

$I N T E R_{i}$ - represents the internationalisation intensity of firm $i$;

INNOV $V_{i}$ - is the innovation intensity of firm $i$;

$\beta$ - is the coefficient of interest;

$\ln (T P R O D)$ - is the natural logarithm of total productivity for firm $i$;

$\ln (L P)$ - is the natural logarithm of labour productivity for the firm $l$;

$\vartheta_{r}$ and $\gamma_{e}$ - are regions and size effects; $\varepsilon_{i}$ is the error term.

The regional effects reflect variation in regional innovation systems (at NUTS-2 level). Size effects are introduced by dummies for micro, small, medium and large enterprises based on their employment with thresholds at 10, 50, 250.

The results of estimation in Table 7 show that higher innovation intensity is strongly correlated with higher internationalisation intensity (01). The relationship is statistically significant at $1 \%$ level. It holds even after control for region and sector fixed effects (O2), to account for immutable characteristics of firms which might induce both innovation and internationalisation. The relationship also holds after controlling for a firmlevel total productivity (O3) or labour productivity (04). However, the impact of total productivity on internationalisation intensity is positive but statistically insignificant. Overall, a unit increase in innovation intensity by a manufacturing firm in our sample is associated on average with an increase of around 0.12 in its internationalisation intensi- 
ty. We have to note the low value of the coefficient of determination. However, the value of this indicator in micro-econometrics is usually very low. The model itself may be fairly correct, but the value of the coefficient of determination will be small - as (Wooldridge 2003; 41) puts it, seemingly low R-squared does not necessarily mean that an OLS regression equation is useless. The $\mathrm{p}$-values of the Shapiro-Wilk $\mathrm{W}$ test obtained indicate that we cannot reject that residuals are normally distributed.

The further econometric analysis on the above result, with the use of MNL, OL and instrumental variables approaches where innovation intensity is estimated with appropriate exogenous instruments, not reported here due to text size limitations (but available upon request), proves the close nexus and provides some evidence for causality going from innovation to internationalisation. This is in line with most of the empirical studies and in contrast to Damijan, Kostevc, \& Polanec (2010) who report learning by exporting - exporting inducing firms to innovate.

The full analysis devoted to all 709 enterprises in our sample, including service providers, and full and detailed description of the employed methodology is available in Brodzicki (2016).

Table 7. Internationalisation and innovation intensity for a sample of Polish manufacturing firms - OLS estimates

\begin{tabular}{|c|c|c|c|c|}
\cline { 2 - 5 } \multicolumn{1}{c|}{} & $\mathbf{0 1}$ & $\mathbf{0 2}$ & $\mathbf{0 3}$ & $\mathbf{0 4}$ \\
\hline INNOV & 0.127 & 0.114 & 0.120 & 0.128 \\
& $(0.038)^{* * *}$ & $(0.037)^{* * *}$ & $(0.038)^{* * *}$ & $(0.037)^{* * *}$ \\
L_TPROD & - & - & 0.029 & - \\
& & & $(0.050)$ & \\
L_LP & - & - & - & 0.105 \\
& & & 2.824 & $(0.046)^{* *}$ \\
Constant & 2.373 & 2.960 & $(0.602)^{* * *}$ & $(0.778)^{* * *}$ \\
& $(0.119)^{* * *}$ & $(0.751)^{* * *}$ & Yes & yes \\
\hline Region & no & yes & Yes & yes \\
Size & no & yes & 0.20 & 0.19 \\
\hline $\mathbf{R}^{2}$ & 0.02 & 0.13 & 478 & 494 \\
$\mathbf{N}$ & 536 & 536 & 7.02 & 6.94 \\
\hline $\mathbf{F}$ & 10.97 & 3.97 & \\
\hline
\end{tabular}

Estimated in STATA. Robust standard errors in parentheses $* * * p<0.01 .{ }^{* *} p<0.05 .{ }^{*} p<0.1$.

Source: own elaboration from the survey and InfoCredit databases.

The estimation results of a logit model for the probability of exporting are presented in Table 8 . We would like to analyse the impact of both internationalisation and innovation intensity on the likelihood of exporting. The dependent variable is binary with one representing success - exports, and zero representing failure - lack of exports (a non-exporter status of a given manufacturing company).

The base model, not taking innovation-related aspects into account, is estimated in the specification L1. Higher productivity (L_TPROD), as expected, has a positive impact on the likelihood of exporting. We also control for other standard features, such as firm size (measured by the log of employment, L_EMPLOY), firm age (FIRM AGE) and other aspects of greater internationalisation, such as importer status (IMPORTER), the presence of foreign capital (FOR.CAPITAL) or foreign capital investments carried out by the company itself (FDI). The coefficients on the base variables are statistically significant. Of 
these, the odds ratio are highest for FDI and imports. The likelihood of exporting increases with firm size, age, as well as firm-productivity (in line with Melitz 2003 theoretical predictions and results of other empirical studies e.g. Bernard \& Jensen 1999, Bernard, Jensen, \& Schott 2006). Even if, as in L2, we replace log of total productivity with a log of labour productivity (L_LP), the results hold and are very close to base specification L1. The use of the log of firm-level TFP would not change the results, either.

In standard econometric modelling goodness of fit is evaluated using the coefficient of determination. For the logit model, McFadden pseudo-R2 measure is typically calculated (McFadden 1974) comparing the estimates of the full model with its reduced form. In addition, in order to assess predictive power of the models we report Akaike information criterion (AIC) and an AUC measure (Area Under the Curve) or the area under the ROC curve (Receiver Operating Characteristic), which is a measure of the ability to distinguish between firms failing to meet the specified set of criteria.

In the next step, we augment the logit analysis by introducing the concepts of innovation and internationalisation intensities defined in the methodological section of the paper. The scope of internationalisation is modified by excluding export-related aspects for obvious reasons (we thus introduce INTER_MOD with variability from 0 to 5 ). As it can be seen in the Table, innovation intensity has a clearly positive impact on the likelihood of exporting by a manufacturing firm whether we control for total productivity (L3) or labour productivity (L4). It is in line with studies like Monreal-Perez, Aragon-Sanchez and Sanchez-Marin (2012) or Van Beveren and Vandenbussche (2010).

If, as in (L5) and (L6), we control simultaneously for the impact of both innovation and internationalisation intensities, after adjusting the base specification accordingly, it is positive and statistically significant. The impact of internationalisation intensity is, however, significantly larger. Nonetheless, a unit increase in innovation intensity by a manufacturing company raises the likelihood of exporting by approx. $37 \%$.

In the last two specifications (L7) and (L8), we control for potential regional variation in innovation systems (Cooke 2002) by adding regional dummies for NUTS 2 voivodeships. It increases the magnitude of the impact of both key variables on the likelihood of exporting. The odds ratio increases to 1.47 and 2.05 respectively. The regional effects are positive, strong and robust in particular for dolnośląskie, śląskie, and wielkopolskie (not reported in Table 8).

\section{CONCLUSIONS}

The paper aimed at the empirical identification of the nexus between the intensity of innovation and the intensity of internationalisation in a sample of Polish manufacturing companies. Using a unique dataset combining micro-level financial data from InfoCredit and results from an extensive survey we were able to reach this goal using descriptive statistics and econometric tools.

We firstly defined the internationalisation and innovation intensities and then analysed firms' mean features along the two examined dimensions disjointly and then concurrently. In addition, we analysed it using the classification of exporters only from Onkelinx and Sleuwaegen (2010) by geographic scope of exports and the moment of commencement of exports in the life-cycle of a firm. 
There is a great deal of heterogeneity in the extent of firms' simultaneous involvement in internationalisation and innovation. Most of the Polish manufacturing companies have unfortunately both low innovation and internationalisation intensity. Companies with high intensities are rare. The joint distribution along two explored dimensions shows an expected pyramidal structure with the peak at low levels of internationalisation and innovation. At the same time, mean characteristics of firms, such as employment, sales or foremost productivity, changes along two scrutinised dimensions. Furthermore, internationalisation and innovation dimensions are closely correlated. There is some evidence for the causality going from innovation to internationalisation. Rising innovation intensity allows companies to become more internationalised and in particular significantly raises their likelihood of exporting. The overall intensity of internationalisation is the lowest for traditional internationalisers and born-again global firms. It is the highest for born globals - the rarest of firms. In terms of innovation intensity, born-again globals, and born internationals have the lowest intensity, while it is significantly higher for traditionally internationalised companies and born globals.

We contribute to the body of literature mainly by using a novel methodology in terms of providing extended definitions of innovation and internationalisation intensities (extending the concept of Altamonte et al. 2013), using a number of statistical and econometric methods to analyse a cross-sectional dataset and finally by conducting the indepth analysis for an interesting case study of economy at the advanced stage of economic transition - namely, Poland. From the Polish perspective, it is one of the first studies of this kind analysing the nexus between internationalisation and innovation at the level of individual firms. using the unique firm level combination of quantitative financial data and qualitative survey data gathered in direct interviews with managers of firms.

Our results firmly support the postulates of the new new trade theory of Melitz (2003) and are to a large extent in line with the outcomes of the benchmark study by Altomonte et al. (2013). With the confirmation of heterogeneous firms trade theory, we should expect its closer cross-fertilisation with the literature on international entrepreneurship and innovation which could advance all three theoretical and empirical literature strands.

The results, moreover, strongly support the introduction of a new type of economic policy in which internationalisation promotion and innovation promotion would be simultaneously targeted at the level of a firm in order to efficiently increase the competitive potential of an economy. For the time being, export promotion policies and innovation policies usually target two separate sets of companies. In contrast to Cieślik et al. (2016), we would not limit the policy to stimulating only product and process innovations. The share of firms introducing innovations and internationalized (exporting, offshoring or active FDI-makers) in the population of firms should be efficiently increased in order to boost the overall competitiveness of the Polish economy and secondly export value per exporting firm should be raised as well.

At the same time, at the level of a firm, innovation strategy should be an integral part of a corporate strategy and the complex nexus between the two should be particularly addressed in the process of internationalisation of business activities (Wach, 2015).

Despite the promising results obtained, many issues still remain open. The major limitation of the analysis is obviously the cross-sectional nature of the dataset utilised Panel dataset would be preferred, however, the qualitative survey was conducted only 
once. The issue of potential endogeneity was addressed to some extent, however, the analysis should be performed preferably on a panel of firms observed at regular intervals over their lifetime in order to fully and extensively verify the causalities between variables. We also expect the impact of innovation to change over time from the moment of introduction - the use of lags in the panel setting should allow us to discriminate between short-run and long-run effects. In future studies, it would be desirable to use extended samples of firms over elongated periods for other case countries to test the robustness of the results and thus to draw universal conclusions.

Table 8. The impact of innovation and internationalisation intensities on the probability of manufacturing firm's exports - logit analysis

\begin{tabular}{|c|c|c|c|c|c|c|c|c|}
\hline & (L1) & (L2) & (L3) & (L4) & (L5) & (L6) & (L7) & (L8) \\
\hline L_TPROD & $\begin{array}{c}0.402^{* * *} \\
(0.134)\end{array}$ & - & $\begin{array}{c}0.379 * * * \\
(0.132)\end{array}$ & - & $\begin{array}{c}0.425^{* * *} \\
(0.131)\end{array}$ & - & $\begin{array}{c}0.478^{* * *} \\
(0.134)\end{array}$ & - \\
\hline L_LP & - & $\begin{array}{c}0.406^{* * * *} \\
(0.109)\end{array}$ & - & $\begin{array}{c}0.393^{* * *} \\
(0.113)\end{array}$ & - & $\begin{array}{c}0.419 * * * \\
(0.107)\end{array}$ & - & $\begin{array}{c}0.424^{* * *} \\
(0.118)\end{array}$ \\
\hline L_EMPLOY & $\begin{array}{c}1.027 * * * \\
(0153)\end{array}$ & $\begin{array}{c}1.039 * * * \\
(0.148)\end{array}$ & $\begin{array}{c}0.972 * * * \\
(0.152)\end{array}$ & $\begin{array}{c}0.992^{* * *} \\
(0.149)\end{array}$ & $\begin{array}{c}0.994^{* * *} \\
(0.140)\end{array}$ & $\begin{array}{c}1.025^{* * *} \\
(0.138)\end{array}$ & $\begin{array}{c}1.071^{* * *} \\
(0.154)\end{array}$ & $\begin{array}{c}1.070 * * * \\
(0.155)\end{array}$ \\
\hline IMPORTS & $\begin{array}{c}1.187^{* * *} \\
(0.267)\end{array}$ & $\begin{array}{c}1.244^{* * *} \\
(0.262)\end{array}$ & $\begin{array}{c}1.184 * * * \\
(0.271)\end{array}$ & $\begin{array}{c}1.228 * * * \\
(0.266)\end{array}$ & - & - & - & - \\
\hline FOR.CAPITAL & $\begin{array}{c}0.024^{* * *} \\
(0.006)\end{array}$ & $\begin{array}{c}0.023^{* * *} \\
(0.006)\end{array}$ & $\begin{array}{c}0.023^{* * *} \\
(0.007)\end{array}$ & $\begin{array}{c}0.022^{* * *} \\
(0.006)\end{array}$ & - & - & - & - \\
\hline FDI & $\begin{array}{c}3.656 * * * \\
(0.903)\end{array}$ & $\begin{array}{c}3.547^{* * * *} \\
(0.896)\end{array}$ & $\begin{array}{c}3.536 * * * \\
(0.948)\end{array}$ & $\begin{array}{c}3.454^{* * *} \\
(0.946)\end{array}$ & - & - & - & - \\
\hline FIRM AGE & $\begin{array}{c}0.042 * * \\
(0.017)\end{array}$ & $\begin{array}{c}0.038^{* * *} \\
(0.015)\end{array}$ & $\begin{array}{c}0.038 * * * \\
(0.017)\end{array}$ & $\begin{array}{c}0.034^{* * *} \\
(0.015)\end{array}$ & $\begin{array}{c}0.039 * * \\
(0.020)\end{array}$ & $\begin{array}{c}0.035^{* *} \\
(0.017)\end{array}$ & $\begin{array}{c}0.044^{* *} \\
(0.022)\end{array}$ & $\begin{array}{c}0.036^{* *} \\
(0.017)\end{array}$ \\
\hline INNOV & - & - & $\begin{array}{c}0.255^{* * *} \\
(0.086)\end{array}$ & $\begin{array}{c}0.255^{* * *} \\
(0.085)\end{array}$ & $\begin{array}{c}0.318^{* * *} \\
(0.086)\end{array}$ & $\begin{array}{c}0.319 * * * \\
(0.084)\end{array}$ & $\begin{array}{r}0.387^{* * *} \\
(0.094)\end{array}$ & $\begin{array}{c}0.392^{* * *} \\
(0.092)\end{array}$ \\
\hline INTERN.MOD & - & - & - & - & $\begin{array}{c}0.655^{* * *} \\
(0.119)\end{array}$ & $\begin{array}{c}0.668^{* * *} \\
(0.123)\end{array}$ & $\begin{array}{c}0.695^{* * *} \\
(0.128)\end{array}$ & $\begin{array}{c}0.718^{* * *} \\
(0.131)\end{array}$ \\
\hline Constant & $\begin{array}{c}-6.036 * * * \\
(0.876) \\
\end{array}$ & $\begin{array}{c}-7.108^{* * *} \\
(1.037) \\
\end{array}$ & $\begin{array}{c}-6.341 * * * \\
(0.882) \\
\end{array}$ & $\begin{array}{c}-7.421 \\
(1.050) \\
\end{array}$ & $\begin{array}{c}-7.029 * * * \\
(0.906) \\
\end{array}$ & $\begin{array}{c}-8.217^{* * *} \\
(1.033) \\
\end{array}$ & $\begin{array}{r}-8.539 * * * \\
(1.163) \\
\end{array}$ & $\begin{array}{c}-9.278^{* * *} \\
(1.278) \\
\end{array}$ \\
\hline Region du & no & no & no & no & no & no & yes & yes \\
\hline No of Observations & 476 & 492 & 476 & 492 & 476 & 492 & 476 & 492 \\
\hline Pseudo R2 & 0.3371 & 0.3319 & 0.3521 & 0.3471 & 0.2847 & 0.2851 & 0.3355 & 0.3305 \\
\hline AIC & 403.02 & 417.16 & 396.22 & 409.99 & 431.77 & 443.41 & 431.96 & 446.02 \\
\hline AUC & 0.8691 & 0.8672 & 0.8764 & 0.8734 & 0.8451 & 0.8433 & 0.8697 & 0.8655 \\
\hline
\end{tabular}

Estimated in STATA 12. Robust standard errors in parentheses $* * * p<0.01 .{ }^{* *} p<0.05 .^{*} p<0.1$. - : variable not taken into account in a given specification. AIC - Akaike information criterion. AUC - the Area Under a ROC Curve.

Source: own elaboration from survey and InfoCredit databases.

\section{REFERENCES}

Adams, J., \& Jaffe, A. (1996). Bounding the Effects of R\&D: An Investigation Using Matched Establishment-Firm Data. The RAND Journal of Economics, 27(4), 700-721.

Altomonte, C., Aquilante, T., Ottaviano, G.M., \& Bekes, G. (2013). Internationalization and Innovation of Firms: Evidence and Policy. Economic Policy, 28(76), 663-700.

Aristei, D., Castellani, D., \& Franco, Ch. (2013). Firms' exporting and importing activities: is there a two-way relationship? Review of World Economics, 149(1), 55-84. 
Aw, B.Y., Roberts, M.J., \& Winston, T. (2007). Export Market Participation, Investments in R\&D and Worker Training, the Evolution of Firm Productivity. The World Economy, 30(1), 83-104.

Aw, B.Y., Roberts, M.J., \& Xu, D. (2011). R\&DInvestment, Exporting, and Productivity Dynamics. American Economic Review, 101(4), 1312-1344.

Barney, J. (1991). Firm resources and sustained competitive advantage. Journal of Management, 17(1), 99-120.

Basile, R. (2001). Export behaviour of Italian manufacturing firms over the nineties: the role of innovation. Research Policy, 30(8), 1185-1201.

Becker, S., \& Egger, P. (2013). Endogenous product versus process innovation and a firm's propensity to export. Empirical Economics, 44(1), 329-354.

Bernard, A.B., \& Jensen, B.J. (1999). Exceptional Exporter Performance: Cause, Effect, or Both?.Journal of International Economics, 47(1), 1-25.

Bernard, A.B., Jensen, B.J., \& Schott, P.K. (2006). Trade Costs, Firms and Productivity. Journal of Monetary Economics, 53(5), 917-937.

Bratti, M., \& Felice, G. (2012). Are Exporters More Likely to Introduce Product Innovations?. The World Economy, 35(11), 1559-1598.

Brodzicki, T. (2016). Innovation intensity as a driver of firm's internationalization intensity Evidence for Poland. Ekonomia - rynek, gospodarka, społeczeństwo, 46, 11-43.

Brodzicki, T., \& Ciołek, D. (2016). Determinanty działalności eksportowej polskich firm produkcyjnych. Gospodarka Narodowa, 2, 59-76.

Caldera, A. (2010). Innovation and exporting: evidence from Spanish manufacturing firms. Review of World Economy, 146(4), 657-689.

Cassiman, B., Golovko, E., \& Martinez-Ros, E. (2010). Innovation, exports and productivity. International Journal of Industrial Organization, 28(4), 372-376.

Cassiman, B., \& Golovko, E. (2011). Innovation and Internationalization Through Exports. Journal of International Business Studies, 42(1), 56-75.

Castellani, D., \& Zanfei, A. (2007). Internationalisation, Innovation and Productivity: How Do Firms Differ in Italy? The World Economy, 30(1), 156-176.

Cieślik, A., Michałek, J.J., \& Michałek, A. (2012). Determinanty działalności eksportowej polskich przedsiębiorstw. Gospodarka narodowa, 7, 67-84.

Cieślik, A., Michałek, J.J, \& Michałek, A. (2014). The Influence of Firm Characteristics and Export Performance in Central and Eastern Europe: Comparisons of Visegrad, Baltic and Caucasus States. Entrepreneurial Business and Economics Review, 2(1), 7-18.

Cieślik, A., Michałek, J.J., \& Szczygielski, K. (2016). Innovations and Export Performance: Firm-level Evidence from Poland. Entrepreneurial Business and Economics Review, 4(4), 11-28.

Cooke, Ph. (2002). Regional innovation systems. The Journal of Technology Transfer, 27(1), 133-145.

Damijan, J., Kostevc, C., \& Polanec, S. (2010). From Innovation to Exporting or Vice Versa? World Economy, 33(3), 374-398.

Dixit, A.K., \& Stiglitz, J.E. (1977). Monopolistic competition and optimum product diversity. American Economic Review, 67(3), 297-308.

Dollar, D. (1986). Technological innovation, capital mobility, and the product cycle in North-South trade. American Economic Review, 76(1), 177-190.

Entorf, H., Krader, W., \& Pohlmeier, W. (1988). Entscheidungen über Innovation, Beschäftigung und Außenhandel: Empirische Ergebnisse eines simultanen Probitansatzes. In: Kräger H. (ed.). Empirische Wirtschaftsforschung (pp. 27-48). Frankfurt: Empirical Research in Economics. 
Garcia-Quevedo, J., Pellegrinoa, G., \& Vivarellic, M. (2014). R\&Ddrivers and age: Are young firms different? Research Policy, 43(9), 1544-1556.

Hagemejer, J., \& Kolasa, M. (2011). Internationalisation and Economic Performance of Enterprises: Evidence from Polish Firm-level Data. World Economy, 34(1), 74-100.

Hirsch, S., \& Bijaoui, I. (1985). R\&DIntensity and export performance: a micro view. Weltwirtschaftliches Archiv, 121(2), 138-151.

Hitt, M.A., Bierman, L., Shimizu, K., \& Kochhar, R. (2001). Direct and moderating effects of human capital on strategy and performance in professional service firms: A resource-based perspective. Academy of Management Journal, 44(1), 13-28.

Jensen, R. \& Thursby, M. (1987). A decision theoretic model of innovation, technology transfer, and trade. Review of Economic Studies, 54(4), 631-647.

Kafouros, M.I., Buckley, P.J., Sharp, J.A., \& Wang, Ch. (2008). The role of internationalization in explaining innovation performance. Technovation, 28(1-2), 63-74.

Krugman, P. (1979). Increasing returns, monopolistic competition, and international trade. Journal of International Economics, 9(4), 469-479.

Krugman, P. (1980). Scale economies, product differentiation, and the pattern of trade. American Economic Review, 70(5), 950-959.

Kumar, N., \& Siddharthan, N.S. (1994). Technology, firm size and export behaviour in developing countries: the case of Indian enterprise. Journal of Development Studies, 32(2), 288-309.

Leonidou, L.C. (1998). Factors stimulating export business: An empirical investigation. Journal of Applied Business Research, 14(2), 43-68.

Lileeva, A., \& Trefler, D. (2010). Improved access to foreign markets raises plant-level productivity for some plants. The Quarterly Journal of Economics, 125(3), 1051-1099.

McFadden, D. (1974). On Conditional logit model of qualitative choice behaviour. In: Zarembka, P. (ed.), Frontiers in Econometrics (pp. 105-142). New York: Academic Press.

Melitz, M.J. (2003). The Impact of Trade on Intra-industry Reallocations and Aggregate Industry Productivity. Econometrica, 71(6), 1695-1725.

Monreal-Perez, J., Aragon-Sanchez, A., \& Sanchez-Marin, G. (2012). A longitudinal study of the relationship between export activity and innovation in the Spanish firm: The moderating role of productivity. International Business Review, 21, 862-877.

Nassimbeni, G. (2001). Technology, innovation capacity, and the export attitude of small manufacturing firms: a logit/tobit model. Research Policy, 30, 245-262.

Nelson, R.R. (1991). Why do firms differ, and how does it matter? Strategic Management Journal, 12(S2), 61-74.

Onkelinx, J., \& Sleuwaegen, L.E. (2010). Internationalization strategy and performance of small and medium-sized enterprises. National Bank of Belgium Working Paper, no. 197.

Posner, M.V. (1961). International trade and technical change. Oxford Economic Papers, 13(3), 323-341.

Roper, S., \& Love, J.H. (2002). Innovation and export performance: evidence from the UK and German manufacturing plants. Research Policy, 31, 1087-1102.

Salomon, R.M., \& Shaver, M.J. (2005). Learning by exporting: New insights from examining firm innovation. Journal of Economics and Management Strategy, 14(2), 431-460.

Segerstrom, P.S., Anant, T.C.A., \& Dinopoulos, E. (1990). A Schumpeterian model of the product life cycle. American Economic Review, 80(5), 1077-1091.

Sterlacchini, A. (1999). Do innovative activities matter to small firms in non-R\&D-intensive industries? An application to export performance. Research Policy 28(8), 819-832. 
Tidd, J., \& Bessant, J. (2009). Managing innovation. Integrating Technological, Market and Organizational Change. Haddington: Wiley and Sons.

Trefler, D. (2004). The Long and Short of the Canada-U.S. Free Trade Agreement. American Economic Review, 94(4), 870-895.

Van Beveren, I., \& Vandenbussche, H. (2010). Product and process innovation and firms' decision to export. Journal of Economic Policy Reform, 13(1), 3-24.

Vernon, R. (1966). International investment and international trade in the product cycle. Quarterly Journal of Economics, 80(2), 190-207.

Wach, K. (2015). Entrepreneurial Orientation and Business Internationalisation Process: The Theoretical Foundations of International Entrepreneurship. Entrepreneurial Business and Economics Review, 3(2), 9-24.

Wakelin, K. (1998). Innovation and export behaviour at the firm level. Research Policy, 26, 829-841.

Wooldridge, J. M. (2003). Introductory econometrics: a modern approach, ed. 2, South-Western.

\section{Author}

\section{Tomasz Brodzicki}

Assistant Professor at the University of Gdansk, Faculty of Economics. Research Partner in Institute for Development, Sopot. His research interests include international economics, economic growth and development, technological progress and innovation.

Correspondence to: Tomasz Brodzicki, PhD, University of Gdansk, Faculty of Economics, ul. Armii Krajowej 119/121, PL 81-824 Sopot, e-mail: t.brodzicki@ug.edu.pl

\section{Acknowledgements and Financial Disclosure}

The paper is a part of a research project supported by a grant from the Polish National Science Centre (No2012/05/B/HS4/04209) carried out at the Institute for Development and chaired by Professor Krystyna Gawlikowska-Hueckel.

\section{Copyright and License}

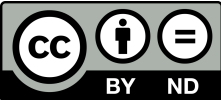

This article is published under the terms of the Creative Commons Attribution - NoDerivs (CC BY- ND 4.0) License http://creativecommons.org/licenses/by-nd/4.0/

Published by the Centre for Strategic and International Entrepreneurship - Krakow, Poland 
